\title{
Stress and neuroinflammation: a systematic review of the effects of stress on microglia and the implications for mental illness
}

\author{
Marilia A. Calcia ${ }^{1}$ - David R. Bonsall ${ }^{2}$ - Peter S. Bloomfield ${ }^{2}$. \\ Sudhakar Selvaraj $^{3} \cdot$ Tatiana Barichello $^{3}$ - Oliver D. Howes ${ }^{1,2}$
}

Received: 28 August 2015 / Accepted: 18 January 2016/Published online: 5 February 2016

(C) The Author(s) 2016. This article is published with open access at Springerlink.com

\begin{abstract}
Rationale Psychosocial stressors are a well-documented risk factor for mental illness. Neuroinflammation, in particular elevated microglial activity, has been proposed to mediate this association. A number of preclinical studies have investigated the effect of stress on microglial activity. However, these have not been systematically reviewed before.

Objectives This study aims to systematically review the effects of stress on microglia, as indexed by the histological microglial marker ionised calcium binding adaptor molecule 1 (Iba-1), and consider the implications of these for the role of stress in the development of mental disorders.

Methods A systematic review was undertaken using predefined search criteria on PubMed and EMBASE. Inclusion and data extraction was agreed by two independent researchers after review of abstracts and full text.

Results Eighteen studies met the inclusion criteria. These used seven different psychosocial stressors, including chronic restraint, social isolation and repeated social defeat in gerbils, mice and/or rats. The hippocampus (11/18 studies) and prefrontal cortex (13/18 studies) were the most frequently studied
\end{abstract}

Marilia A. Calcia and David R. Bonsall contributed equally to this work.

David R. Bonsall

d.bonsall@csc.mrc.ac.uk

1 Department of Psychosis Studies, Institute of Psychiatry, Neurology and Neuroscience (IoPPN), King's College London, Denmark Hill, London SE5 8AZ, UK

2 Psychiatric Imaging Group, Imperial College, MRC Clinical Sciences Centre, Hammersmith Hospital, London W12 0NN, UK

3 Department of Psychiatry and Behavioural Sciences, The University of Texas Health Science Centre at Houston, Houston, TX 77054, USA areas. Within the hippocampus, increased Iba-1 levels of between 20 and $200 \%$ were reported by all 11 studies; however, one study found this to be a duration-dependent effect. Of those examining the prefrontal cortex, $\sim 75 \%$ found psychosocial stress resulted in elevated Iba- 1 activity. Elevations were also consistently seen in the nucleus accumbens, and under some stress conditions in the amygdala and paraventricular nucleus.

Conclusions There is consistent evidence that a range of psychosocial stressors lead to elevated microglial activity in the hippocampus and good evidence that this is also the case in other brain regions. These effects were seen with early-life/prenatal stress, as well as stressors in adulthood. We consider these findings in terms of the two-hit hypothesis, which proposes that early-life stress primes microglia, leading to a potentiated response to subsequent stress. The implications for understanding the pathoaetiology of mental disorders and the development of new treatments are also considered.

Keywords Stress $\cdot$ Inflammation $\cdot$ Microglia $\cdot$ Psychosis · Neuroinflammation

\section{Introduction}

Large-scale epidemiological studies have shown that stress, both early in childhood and later in life, predisposes to the development of mental health problems in adulthood (Scott et al. 2012; Varese et al. 2012; Benjet et al. 2010; Kessler et al. 2010). Several hypotheses, including alterations in the hypothalamic-pituitary stress system, abnormal immunological responses and lasting changes in cellular, molecular and epigenetic forms of plasticity, have been proposed to explain 
the neurobiological pathways that link childhood adversities to later development of adult mental illnesses.

The immune system responds to stressors and communicates with the central nervous system through a number of mechanisms, including cytokine signalling, vagal innervation and the lymphatic system (Louveau et al. 2015; Dantzer et al. 2008; Wan et al. 1994). It has been reported that stressful life experiences are associated with elevated pro-inflammatory cytokines in childhood and are also associated with the high risk of mental illness in adulthood (Khandaker et al. 2014; Danese et al. 2008). Such cytokine elevations may induce changes to cortical microglia, which in turn may be associated with structural and functional changes in the brain that predispose individuals to mental illness (see review by Réus et al. 2015). Supporting this, changes in microglial markers have been reported in a number of mental disorders such as depression (Torres-Platas et al. 2014), anxiety (Frick et al. 2013), schizophrenia (van Berckel et al. 2008) and autism spectrum disorders (Réus et al. 2015; Morgan et al. 2012). A recent PET imaging study demonstrated increased microglial activity in patients with schizophrenia and persons who are at ultra high risk of psychosis. Furthermore, greater microglial activity was positively correlated with greater symptom severity in the atrisk population (Bloomfield et al. 2015), suggesting a link between neuroinflammation and risk of psychosis.

Microglia are myeloid cells which provide the main form of adaptive immune response in the central nervous system (CNS). These cells modulate neuronal function not only during an inflammatory response but also during developmental synaptic pruning (Paolicelli et al. 2011) and plasticity in the healthy brain (Parkhurst et al. 2013; Tremblay et al. 2010) and are able to rapidly respond to even minor changes in the brain
(Lawson et al. 1990). Microglia monitor the functional state of synapses, influence neuroplastic changes by remodelling extracellular spaces and eliminate synaptic elements by phagocytosis (Brown and Neher 2014; Kettenmann et al. 2013; Schafer and Stevens 2010).

In response to harmful stimuli, microglia undergo a number of changes (Walker et al. 2014). These include an increase in number due to proliferation (Kettenmann et al. 2011) and through recruitment of monocytes from the peripheral blood (Wohleb et al. 2013). Production of pro-inflammatory cytokines and the expression of several cell surface antigens are also features of inflammatory microglial response (Table 1). Of these, Iba-1 has been widely used to study microglia as its expression is specific and is expressed by both reactive and quiescent microglial cells (Frick et al. 2013).

In the healthy adult central nervous system, microglia have a ramified morphology (Fig. 1), characterised by long, thin processes that enable the microglia to search the local environment for infectious agents or harmful material (Nimmerjahn et al. 2005). When responding to insults, the processes retract, and the cell body enlarges, giving the microglia an amoeboid shape (Cho et al. 2006; Davalos et al. 2005). Chronic inflammatory states are associated with a hypertrophic branch morphology with an enlarged soma (Loane et al. 2014; Hains and Waxman 2006; Stalder et al. 1999). Some of these changes have been shown to occur not only in response to classical inflammatory stimuli, such as infection, but also to psychological stress (Hinwood et al. 2012; Tynan et al. 2010; Sugama et al. 2007; reviewed by Walker et al. 2013).

Here, we aim to review the recent preclinical literature to examine the effects of psychosocial stressors on microglial

Table 1 Common surface antigen markers of microglia and other centrally active immune cells

\begin{tabular}{|c|c|c|}
\hline Marker & Function & Microglial significance \\
\hline CD68 & Involved in phagocytosis (Ramprasad et al. 1996) & Localised to monocytes and neutrophils (Saito et al. 1991) \\
\hline CD11b (complement receptor 3) & $\begin{array}{l}\text { Regulates leukocyte adhesion and } \\
\text { migration to mediate inflammatory } \\
\text { response (Meerschaert and Furie 1995) }\end{array}$ & $\begin{array}{l}\text { Expressed in neutrophils, monocytes, } \\
\text { natural killer cells, specific lymphocytes (Arnaout 1990) }\end{array}$ \\
\hline $\begin{array}{l}\text { Ionised calcium binding adapter } \\
\text { molecule } 1 \text { (Iba-1) }\end{array}$ & $\begin{array}{l}\text { Role in membrane ruffling and phagocytosis } \\
\text { (Ohsawa et al. 2000) }\end{array}$ & $\begin{array}{l}\text { Expressed centrally by microglia and infiltrating } \\
\text { macrophage (Wohleb et al. 2013, Ito et al. 1998) }\end{array}$ \\
\hline $\mathrm{CD} 45$ & $\begin{array}{l}\text { Modulates activation and proliferation of } \\
\text { inflammatory cell types } \\
\text { (Huntington and Tarlinton 2004) }\end{array}$ & $\begin{array}{l}\mathrm{CD} 45_{\text {low }} \text { - quiescent microglia } \\
\mathrm{CD} 45_{\text {high }} \text { - peripheral monocytes (Denker et al. 2007) }\end{array}$ \\
\hline IL-1 $\beta$, TNF- $\alpha$, IL-6 & Pro-inflammatory cytokines & $\begin{array}{l}\text { Released by stimulated neutrophils and monocytes } \\
\text { (Konsman et al. 2002) }\end{array}$ \\
\hline MHC-II & $\begin{array}{l}\text { Role in antigen presentation to T cells } \\
\text { (St Pierre and Watts 1991) }\end{array}$ & $\begin{array}{l}\text { Expressed centrally by stimulated microglia and } \\
\text { macrophage (Aloisi 2001; Xu and Ling 1994) }\end{array}$ \\
\hline CCL2/MCP-1 & $\begin{array}{l}\text { Triggers microglial proliferation and recruits } \\
\text { other pro-inflammatory cells (Hinojosa et al. 2011) }\end{array}$ & $\begin{array}{l}\text { Produced by stimulated microglia and expressed in high } \\
\text { levels by infiltrating macrophage (Selenica et al. 2013) }\end{array}$ \\
\hline CX3CR1 (fractalkine receptor) & $\begin{array}{l}\text { Role in leukocyte migration and adhesion } \\
\text { (Imai et al. 1997) }\end{array}$ & $\begin{array}{l}\mathrm{CCR} 2_{\text {low }} / \mathrm{CX} 3 \mathrm{CR} 1_{\text {high }} \text { - microglia CCR } 2_{\text {high }} / \\
\mathrm{CX} 3 \mathrm{CR} 1_{\text {low }}-\text { monocytes (Mizutani et al. } 2012 \text { ) }\end{array}$ \\
\hline
\end{tabular}




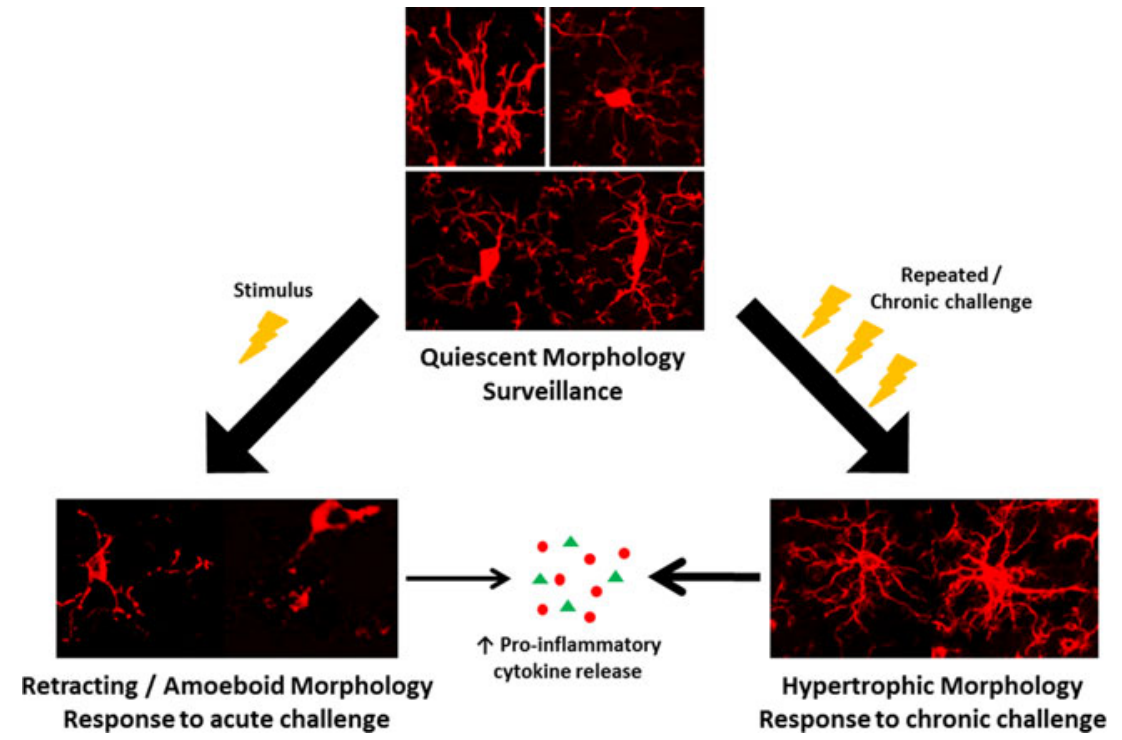

Fig. 1 Morphological changes to microglia in response to challenge. In the healthy brain, most microglia display a 'quiescent' morphology as they survey the brain. In response to a challenge (lightning bolt), such as stress, microglia take on an amoeboid morphology as their processes

retract and the soma enlarges. After chronic exposure to CNS challenges, microglia become hypertrophic and primed. Primed microglia produce an exaggerated cytokine response to a subsequent challenge

activity and assess the strength of evidence for a link between stress and microglial changes. For the purposes of this review, we limited our search to studies that utilised the ionised calcium binding adaptor molecule 1 (Iba-1) as a measure of microglial activity, as Iba-1 is expressed by microglia independent of cellular context (Ito et al. 1998), and is widely used, thereby making comparisons across studies possible.

\section{Methods}

\section{Stress definition}

For the purpose of this review, stress was defined as experimental paradigms causing contextual distress to animals. These include physical stimuli such as handling restraint, occlusal disharmony and foot shock, as well as environmental stressors; social isolation, overnight food/water deprivation, social defeat and home cage disruptions (Table 2). These stimuli have been previously validated as effective preclinical models of the social stressors associated with an increased risk of mental illness in humans (Blanchard et al. 2001).

\section{Search approach}

Preclinical studies on the effects of stress on the microglia were identified from electronic searches of PubMed and EMBASE (Fig. 2). We used the following MeSH and free form search terms: stress OR isolation OR defeat OR restraint
AND microglia* NOT oxidative NOT spinal NOT retina. The search was performed in June 2015 and limited to studies published between 2000 and 31 May 2015. Reference lists and abstracts of the papers identified by the search were screened to identify additional reports meeting selection criteria. Furthermore, where studies reported incomplete information, authors were contacted to request supplementary data.

\section{Screen and exclusion criteria}

The inclusion criteria were (1) original studies; (2) investigated the effect of psychosocial stress on microglial number, morphology or changes indexed Iba-1; (3) published in English, Spanish, Portuguese or Italian; and (4) published in a peer-reviewed journal.

Studies were excluded if they referred to microglia outside of the brain (i.e. in the spinal cord or retina); if the primary stress was pathological, oxidative or related to neurological (e.g. stroke, nerve damage) or systemic disease, hypo/hyperglycaemia or hypoxia; or if the microglial markers did not include Iba-1 measures. We excluded review articles, letters, comments, multiple publications of the same data and articles that did not publish information necessary to calculate effect sizes or percentage change from baseline.

\section{Data extraction}

We adhered to the 'Meta-analysis of Observational Studies in Epidemiology' (MOOSE) reporting guidelines 
Table 2 Preclinical models of psychosocial stress

\begin{tabular}{|c|c|c|c|c|}
\hline Stressor & Species & $\begin{array}{l}\text { Stress } \\
\text { duration }\end{array}$ & Description & References \\
\hline Foot shock & C57B1/6 mice & 5 days & $\begin{array}{l}\text { Each day, mice were individually placed } \\
\text { into a foot-shock box and received } \\
120 \text { shocks }(5 \mathrm{~s} \text { of } 0.15 \mathrm{~mA} / 30 \mathrm{~s}) \\
\text { over the period of an hour. Control } \\
\text { animals were placed into the foot- } \\
\text { shock box for } 1 \mathrm{~h} / \text { day without any } \\
\text { foot shocks. }\end{array}$ & Brevet et al. (2010) \\
\hline Chronic restraint & $\begin{array}{r}\text { Sprague-Dawley rats, } \\
\text { Mongolian gerbils }\end{array}$ & 14-21 days & $\begin{array}{l}\text { Animals placed within restrictive wire } \\
\text { mesh/Plexiglas environments for up } \\
\text { to } 6 \mathrm{~h} / \text { day over the stress duration. } \\
\text { Control animals were handled each } \\
\text { day and returned to their home cage }\end{array}$ & $\begin{array}{l}\text { Tynan et al. (2010), Park } \\
\text { et al. (2011), Yoo et al. } \\
\text { (2011), Hinwood et al. } \\
\text { (2012, 2013), Kopp } \\
\text { et al. (2013) }\end{array}$ \\
\hline Occlusal disharmony & ddY mice & $1-5$ days & $\begin{array}{l}\text { Surgical placement of resin on the upper } \\
\text { molars increased the vertical } \\
\text { dimension of the bite by } 0.1 \mathrm{~mm} \text {. } \\
\text { Mice were returned to their home } \\
\text { cage for up to } 5 \text { days post-surgery } \\
\text { with food ad lib. Control mice } \\
\text { underwent sham surgery. }\end{array}$ & Kojo et al. (2010) \\
\hline $\begin{array}{l}\text { Prenatal stress/ } \\
\text { maternal restraint }\end{array}$ & $\begin{array}{l}\text { Sprague-Dawley rats, } \\
\text { C57B1/6 mice }\end{array}$ & $\begin{array}{l}\text { Gestational } \\
\text { day } 12 / \\
14 \\
\text { delivery }\end{array}$ & $\begin{array}{l}\text { Each day, pregnant females were } \\
\text { restrained in restrictive plastic-box } \\
\text { environments, with exposure to } \\
\text { bright light. Each stress session lasted } \\
45 \text { min and occurred } 3 \text { times/ } \\
\text { day until delivery. Prenatally stressed } \\
\text { offspring were assessed when they } \\
\text { reached 3-4 months old. }\end{array}$ & $\begin{array}{l}\text { Diz-Chaves et al. } \\
\text { (2012, 2013), } \\
\text { Ślusarczyk et al. } \\
\text { (2015) }\end{array}$ \\
\hline $\begin{array}{l}\text { Repeated social } \\
\text { defeat }\end{array}$ & $\mathrm{C} 57 \mathrm{B1} / 6$ mice & 6 days & $\begin{array}{l}\text { Over the } 6 \text { days, an intruder (12-month- } \\
\text { old retired breeder CD- } 1 \text { mouse) was } \\
\text { placed into the home cage of } 3 \text { male } \\
\mathrm{C} 57 \mathrm{Bl} / 6 \text { mice for } 2 \mathrm{~h} / \text { day and } \\
\text { asserted dominance over the } \\
\text { subordinate resident mice. Control } \\
\mathrm{C} 57 \mathrm{Bl} / 6 \text { mice were housed elsewhere } \\
\text { and left without disruption by an } \\
\text { intruder. }\end{array}$ & $\begin{array}{l}\text { Wohleb et al. } \\
\qquad(2011,2012)\end{array}$ \\
\hline Social isolation & Wistar rats & 49 days & $\begin{array}{l}\text { Animals were individually housed } \\
\text { without physical contact with other } \\
\text { rats for the stress duration. Control } \\
\text { animals ( } 4-5 / \text { cage) were housed in } \\
\text { the same room allowing visual, } \\
\text { auditory and olfactory stimulation. }\end{array}$ & Schiavone et al. (2009) \\
\hline $\begin{array}{l}\text { Varying } \\
\text { unpredictable } \\
\text { stress }\end{array}$ & $\begin{array}{l}\text { Sprague-Dawley rats, } \\
\text { C57B1/6, Kunming } \\
\text { mice }\end{array}$ & 2-40 days & $\begin{array}{l}\text { Animals were subjected to } 2-3 \text { different } \\
\text { stressors/day for the duration of the } \\
\text { protocol. Stressors include foot } \\
\text { shock, restraint, water/food } \\
\text { deprivation, forced swim, home cage } \\
\text { disruptions, altered light/dark regimes, and } \\
\text { overcrowding }\end{array}$ & $\begin{array}{l}\text { Bian et al. (2010), Couch } \\
\text { et al. (2013), Giovanoli } \\
\text { et al. (2013), Kopp } \\
\text { et al. (2013), Kreisel } \\
\text { et al. (2014) }\end{array}$ \\
\hline
\end{tabular}

(Stroup et al. 2000). Data were extracted independently by $\mathrm{MC}$ and $\mathrm{DB}$, and agreement was confirmed by O.H. For each study, the following variables were recorded: (a) year of publication, (b) type of stress, (c) animal model, (d) brain areas studied, (e) microglia markers and (f) results.

\section{Results}

\section{Studies}

A total of 18 studies were identified that fitted the search criteria. These studies consisted of seven different stress 


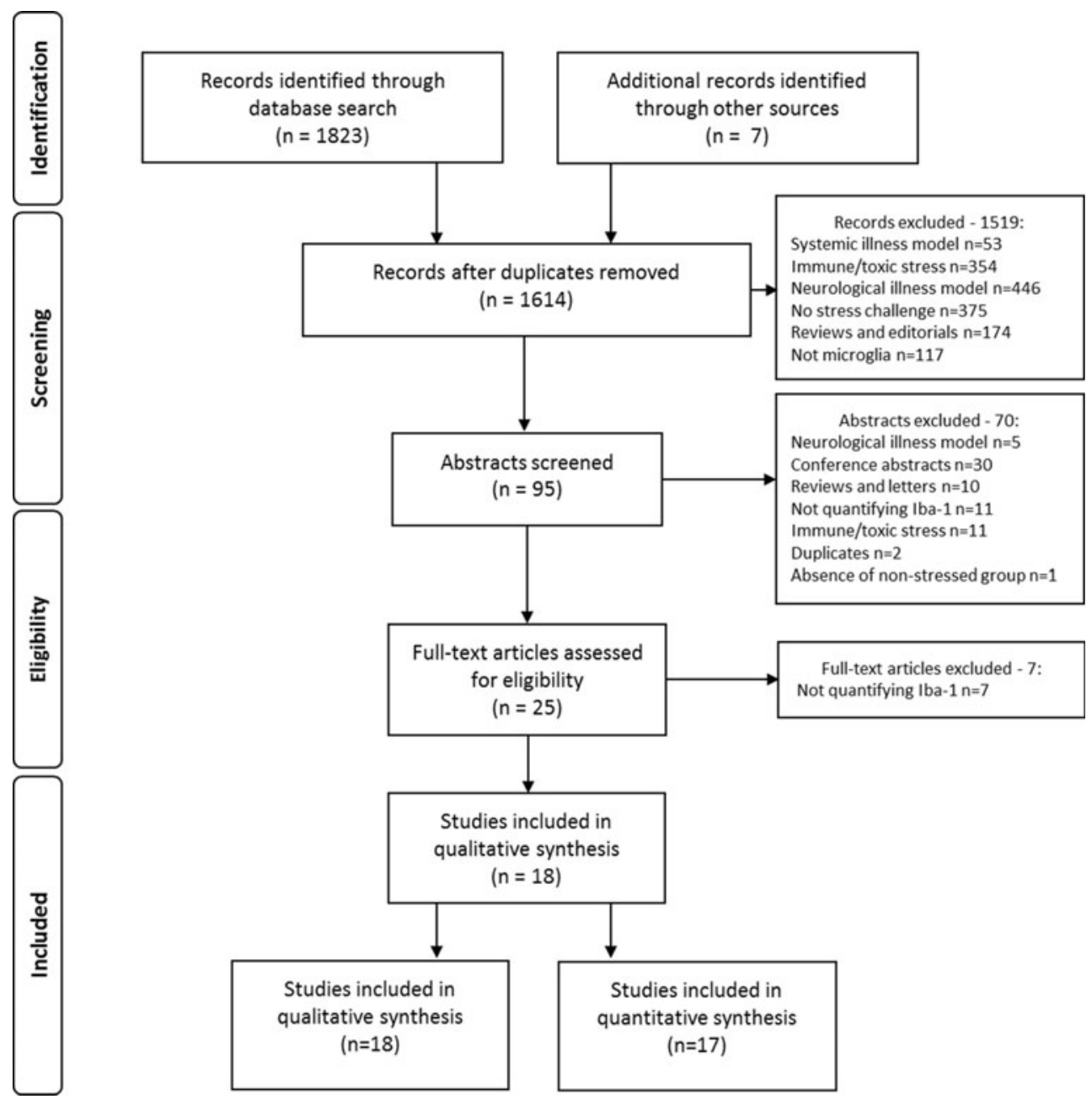

Fig. 2 Workflow of study identification and screening process. Systemic-illness models include liver disease, kidney disease and other systemic noninfectious diseases. Neurological-illness models include brain injury or trauma, neurodegenerative disorders and other neurological illnesses

protocols, including social isolation, chronic restraint, repeated social defeat, occlusal disharmony, foot shock, prenatal stress and a combination of varying unpredictable stressors (Table 2). Three species were used in these studies; rats (Wistar and Sprague-Dawley), mice (C57Bl/6, Kunming and ddY) and the Mongolian gerbil. One study (Kreisel et al. 2014) performed varying unpredictable stress under four separate conditions (using two species and two durations of stress exposure). All four conditions were included in the analysis, making a total of 21 stress paradigms examined.

Amongst the 18 studies, three main methodologies were used to measure Iba-1-associated microglial activity: western blot (Ślusarczyk et al. 2015; Schiavone et al. 2009), real-time PCR (Kreisel et al. 2014) and, for the remaining studies, immunohistochemistry techniques. Analysis of Iba-1 staining consisted of region-specific cell counting (Giovanoli et al. 2013; Hinwood et al. 2013; Kopp et al. 2013; Hinwood et al. 2012; Wohleb et al. 2012, 2011; Kojo et al. 2010;
Tynan et al. 2010) and/or changes in the percentage area occupied by Iba-1 signal per region (Kreisel et al. 2014; Couch et al. 2013; Diz-Chaves et al. 2013; Hinwood et al. 2013, 2012; Kopp et al. 2013; Bian et al. 2012; Diz-Chaves et al. 2012; Park et al. 2011; Yoo et al. 2011; Brevet et al. 2010; Tynan et al. 2010). The findings are summarised in Table 3. The hippocampus and prefrontal cortex were the most commonly studied regions.

\section{Effect of psychosocial stress on Iba-1 activity within the hippocampus}

The effect of stress on Iba-1 activity within the hippocampus was investigated by 11 of the studies, incorporating 13 different stress protocols. These included foot shock (one study), occlusal disharmony (one study), chronic restraint (two studies), repeated social defeat (two studies), prenatal stress (three studies) and varying unpredictable stress (four protocols in two studies). The variable unpredictable stress regimes 
Table 3 Effect of stress on microglial activity as measured by Iba-1

\begin{tabular}{|c|c|c|c|c|}
\hline Brain region & Stressor & Effect on Iba-1 & Species & References \\
\hline \multirow[t]{2}{*}{ Amygdala } & Repeated social defeat & $\uparrow \uparrow \uparrow$ & Mouse & Wohleb et al. $(2011,2012)$ \\
\hline & Chronic restraint & $\rightarrow$ & Rat & Tynan et al. (2010) \\
\hline \multirow[t]{4}{*}{ Hippocampus } & $\begin{array}{l}\text { Repeated social defeat, varying } \\
\text { unpredictable stress, } \\
\text { prenatal stress }\end{array}$ & $\uparrow \uparrow \uparrow$ & Rat, mouse & $\begin{array}{l}\text { Bian et al. (2012), Wohleb et al. (2011, 2012), } \\
\text { Ślusarczyk et al. (2015) }\end{array}$ \\
\hline & $\begin{array}{l}\text { Chronic restraint, prenatal } \\
\text { stress }\end{array}$ & $\uparrow \uparrow$ & Rat, gerbil, mouse & $\begin{array}{l}\text { Tynan et al. (2010), Park et al. (2011), } \\
\text { Yoo et al. (2011), }{ }^{\text {a }} \text { Diz-Chaves et al. } \\
(2012,2013)\end{array}$ \\
\hline & $\begin{array}{l}\text { Varying unpredictable stress, } \\
\text { occlusal disharmony, foot } \\
\text { shock }\end{array}$ & $\uparrow$ & $\begin{array}{l}\text { Rat, adult/peripubertal } \\
\text { mouse }\end{array}$ & $\begin{array}{l}\text { Brevet et al. (2010), Kojo et al. (2010), } \\
\text { Giovanoli et al. (2013), Kreisel et al.(2014) }\end{array}$ \\
\hline & $\begin{array}{l}\text { Chronic varying unpredictable } \\
\text { stress }\end{array}$ & $\downarrow$ & Rat, mouse & Kreisel et al. (2014) \\
\hline \multirow[t]{2}{*}{ Nucleus accumbens } & Social isolation & $\uparrow \uparrow \uparrow$ & Rat & Schiavone et al. (2009) \\
\hline & Chronic restraint & $\uparrow \uparrow$ & Rat & Tynan et al. (2010) \\
\hline \multirow{2}{*}{$\begin{array}{l}\text { Paraventricular } \\
\text { nucleus }\end{array}$} & Repeated Social Defeat & $\uparrow \uparrow \uparrow$ & Mouse & Wohleb et al. $(2011,2012)$ \\
\hline & $\begin{array}{l}\text { Chronic restraint, chronic } \\
\text { varying unpredictable stress }\end{array}$ & $\rightarrow$ & Rat & Tynan et al. (2010) and Kopp et al. (2013) \\
\hline \multirow[t]{4}{*}{ Prefrontal cortex } & $\begin{array}{l}\text { Repeated social defeat, varying } \\
\text { unpredictable stress }\end{array}$ & $\uparrow \uparrow \uparrow$ & Mouse & Bian et al. (2012), Wohleb et al. $(2011,2012)$ \\
\hline & Prenatal stress & $\uparrow \uparrow$ & Rat & Ślusarczyk et al. (2015) \\
\hline & $\begin{array}{l}\text { Social isolation, chronic } \\
\text { restraint, varying } \\
\text { unpredictable stress }\end{array}$ & $\uparrow$ & Rat, mouse & $\begin{array}{l}\text { Schiavone et al. (2009), Tynan et al. (2010), } \\
\text { Hinwood et al. (2012, 2013), } \\
\text { Couch et al. (2013), Kopp et al. (2013) }\end{array}$ \\
\hline & Varying unpredictable stress & $\rightarrow$ & rat, mouse & $\begin{array}{l}\text { Giovanoli et al. (2013), Kopp et al. (2013), } \\
\text { Kreisel et al. (2014) }\end{array}$ \\
\hline Ventral tegmental area & Chronic restraint & $\rightarrow$ & Rat & Tynan et al. (2010) \\
\hline
\end{tabular}

Measure of change in Iba- 1 activity by stress protocol relative to unstressed control animals: no significant change $(\rightarrow),>5 \%$ decrease $(\downarrow), 5-30 \%$ increase $(\uparrow), 30-70 \%$ increase $(\uparrow \uparrow)$ and $>70 \%$ increase $(\uparrow \uparrow \uparrow)$

${ }^{\text {a }}$ As reported by authors

comprised a number of random home cage disruptions, including tilting, background noise, mistimed light exposure, restraint and foot shock over $2-4$ days (two protocols) or 10-35 days (two protocols).

When compared with unstressed control animals, 11 of the 13 protocols in all 11 studies reported significantly increased Iba-1 activity within the hippocampus. The magnitude of these increases varied across protocols, with repeated social defeat resulting in a more than 2 -fold increase in the number of Iba-1-positive cells present (Wohleb et al. 2011), whereas occlusal disharmony, foot shock and varying unpredictable stress led to more moderate increases of $16-27 \%$ (Table 3 ). The changes in Iba-1 were not consistent across the whole hippocampus. Kreisel et al. (2014) demonstrated a $30 \%$ increase in Iba- 1 messenger RNA (mRNA) and $50 \%$ increase in Iba- 1 staining in the dentate gyrus of rats and mice, respectively, following 24 days of variable unpredictable stress. In contrast, after 5 days of occlusal disharmony, Kojo et al. (2010) did not observe any significant changes in the number of Iba-1positive cells within the dentate gyrus of mice, but saw increased Iba-1-positive cell counts in the CA1 region of the hippocampus. This was in line with the 2-fold increase in Iba-1 staining reported in the CA1 region following 40 days of varying unpredictable stress by Bian et al. (2012).

Furthermore, studies of prenatal stress by Diz-Chaves et al. (2012, 2013) found sex differences within the dentate gyrus; prenatally stressed female offspring showed increased number of Iba-1-positive cells in the dentate gyrus whereas males did not show a significant change. Despite no change in the number of cells, the Iba-1 signal was significantly increased within the dentate gyrus of prenatally stressed male mice. No significant changes in Iba-1 activity were reported in the CA1 region of male mice.

Interestingly, Kreisel et al. (2014) found differences in Iba-1 signal between their two protocols. Whereas shortterm exposure (2-4 days) to varying unpredictable stress led to increased hippocampal Iba-1 signal, longer exposure (35 days) was observed to decrease Iba- 1 mRNA in the dentate gyrus of both rats (35\% decrease) and mice (27\% decrease). 
Only one study examined the effect of stress within the CA3 region of the hippocampus. Tynan et al. (2010) found that 14 days of chronic restraint in Sprague-Dawley rats resulted in a moderate increase $(22 \%)$ in the number of Iba-1-positive cells. There was however, an increase of approximately $60 \%$ in the density of Iba- 1 signal within the $\mathrm{CA} 3$ region of the same subjects.

\section{Effect of psychosocial stress on Iba-1 activity within the prefrontal cortex}

Changes in Iba-1 signal within the prefrontal cortex were examined by 13 of the studies using five different stressors. These included social isolation (one study), prenatal stress (one study), repeated social defeat (two studies), chronic restraint (four studies) and varying unpredictable stress (five studies).

Social isolation of adult rats for 35 days resulted in $\sim 15 \%$ increase in Iba-1-positive protein in the prefrontal cortex (Schiavone et al. 2009). This was comparable with the increase in Iba-1-positive cell counts reported by Tynan et al. (2010), following chronic restraint of rats for an hour a day for 14 days. Notably, these rats were also individually housed at the start of the study (and acclimatised for at least 7 days). Further analysis by Hinwood et al. (2013) found that chronic restraint led to distinct morphological changes, with increased ramification of the microglia. A more recent study by Kopp et al. (2013), which restrained rats for only $30 \mathrm{~min}$ a day for 14 days, found that while there was a significant increase in the percentage area of Iba-1 signal throughout the prefrontal cortex (11\% increase), there was no significant change in the number of Iba-1-positive cells. Using an alternative stressor, the varying unpredictable stress protocol, Kopp et al. (2013) found no significant changes in Iba-1 activity in the prefrontal cortex of rats. In mice, the varying stress protocol has produced similarly varied responses in prefrontal cortex Iba-1 activity (Kreisel et al. 2014; Couch et al. 2013; Bian et al. 2012). The greatest changes within the prefrontal cortex were produced in mice undergoing repeated social defeat for 6 days, which resulted in a 2-fold increase in Iba-1 staining (Wohleb et al. 2012, 2011).

\section{Psychosocial stress affects Iba-1 activity in other brain areas}

In addition to the hippocampus and prefrontal cortex, five studies examined the effect of psychosocial stress on Iba-1 activity in other areas of the brain.

Within the nucleus accumbens, both chronic restraint and social isolation of rats resulted in significant increases in Iba-1 activity by $\sim 20-40 \%$ (Iba- 1 cell counts and density) and $73 \%$ (protein density), respectively (Tynan et al. 2010; Schiavone et al. 2009).
Two studies by the same lab used repeated social defeat in mice for 6 days and found significant increases in the number of Iba-1-positive cells in the amygdala (1.6-2.4-fold) and paraventricular nucleus (1.5-2.8-fold) of the hypothalamus (Wohleb et al. 2012, 2011). These findings were in contrast to those produced by chronic restraint and varying unpredictable stress models which found no significant changes in Iba1 within the amygdala (Tynan et al. 2010) or paraventricular nucleus (Kopp et al. 2013; Tynan et al. 2010).

Lastly, only the study by Tynan et al. (2010) examined the ventral tegmental area and found that chronic restraint in rats did not lead to any significant changes in Iba-1 when compared with control animals. This included both in the number of Iba-1-positive cells as well as the percentage change in area covered by Iba-1 signal.

\section{Discussion}

We identified 18 studies showing that psychosocial stress increases expression of the microglial marker Iba-1 in at least one of the brain regions examined by each study and in many cases, in multiple brain areas. These findings support the hypothesis that exposure to psychosocial stress increases the risk of a number of mental illnesses through the activation of microglia and other centrally mediated immune responses (Frick et al. 2013; Nair and Bonneau 2006).

\section{Potential mechanisms}

The expression of glucocorticoid receptors in the brain is greatest within the hippocampus, making it an area particularly sensitive to stress-inducing stimuli (McEwen et al. 1992; Aronsson et al. 1988). Similarly, the prefrontal cortex has a high number of glucocorticoid binding sites and has been implicated in the body's response to stress-signalling via mediation of the hypothalamic-pituitary adrenal (HPA) axis (Gold 2015; Diorio et al. 1993). Furthermore, several studies have demonstrated the negative impact of similar stress protocols on learning and memory (Lemaire et al. 2000; Lordi et al. 1997). Hence, it is not surprising that of the 18 studies identified, 13 investigated stress-associated changes in microglial activity within the hippocampus and 12 within the prefrontal cortex.

In rodents, activation of the HPA axis following stress results in a surge of circulating corticosterone (Meaney et al. 1994). In view of the high number of glucocorticoid receptors present in the hippocampus and prefrontal cortex, these regions are likely to be particularly sensitive to the corticosterone surge, leading to indirect effects on microglia in these regions. In addition, as microglia express both glucocorticoid and mineralocorticoid receptors (Sierra 
et al. 2008), there may be direct effects of stress-induced corticosterone surges on microglia. Increased Iba-1 signal within the hippocampus was reported by all 13 studies, although one of these studies also reported decreased Iba1 when utilising a longer stress duration paradigm (Kreisel et al. 2014). These differences in Iba-1 may reflect changes in HPA-axis regulation, whereby in response to chronic stress, negative feedback mechanisms via glucocorticoid receptor activation leads to reduced corticosterone release (Adzic et al. 2009; Sánchez et al. 1998).

The response of the immune system is known to change with both duration and frequency of stress exposure as the organism attempts to adapt (McEwen 2000). One mechanism by which this occurs is through priming of the nucleotide-binding domain, leucine-rich repeat, pyrin domain-containing proteins-3 (NLRP3) inflammasome, a component of myeloid cells including macrophage and microglia involved in cleaving pro-IL-1 $\beta$ into its active form (Martinon et al. 2002). A recent study by Frank et al. (2014) demonstrated that chronic treatment with glucocorticoids dose-dependently increased expression of NLRP3 and Iba-1 within the hippocampus. Furthermore, subsequent immune challenge with LPS resulted in a potentiated microglial response indicative of priming.

In the study by Giovanoli et al., which found no change in Iba-1 within the prefrontal cortex but moderate increases in the hippocampus, a suggested explanation may be through permanent modifications in the HPA-axis caused by maternal stress (Baquedano et al. 2011; Brunson et al. 2001a, b). Maternal stress acts, at least partly, via changing glucocorticoid action in the placenta impacting the behaviour of offspring (Räikkönen et al. 2015). Prenatal stress also increases IL-1 $\beta$ mRNA levels in the hippocampus and the proportion of microglia cells with large somas during adult life of rodents (Diz-Chaves et al. 2012). Of particular interest is the subsequent immune response of the prenatally stressed offspring. A second systemic immune stimulus given later in life, such as exposure to lipopolysaccharide (LPS), exacerbates the immune response and corticosterone levels in the adult rats (Diz-Chaves et al. 2013). The importance of this finding and the impact of early-life stress exposure on subsequent later-life behaviours and health have only recently been explored (Réus et al. 2015).

In addition to the release of glucocorticoids, psychosocial stress may exert direct effects on microglial activity through other pathways, including the sympathetic release of noradrenaline and subsequent activation of $\beta$-adrenergic receptors. This activation during stress has been associated with increased pro-inflammatory cytokine (IL-1 $\beta$ ) expression within the central nervous system, leading to potential priming of microglia (Johnson et al. 2008, 2005, 2013; McNamee et al. 2010). Furthermore, using the $\beta$-adrenergic antagonist propranolol, Wohleb et al. (2011) effectively blocked the increased Iba-1 signal induced by social defeat in multiple brain regions including the hippocampus and prefrontal cortex.

\section{Implications for understanding the pathoaetiology of mental illnesses}

The general trend resulting from nearly all of the stress paradigms examined suggest that exposure to stress can lead to significant increases in microglial activity. This finding could have implications for mental health research, with studies indicating increased microglial activity prevalent amongst patients with depression, anxiety and schizophrenia (Bloomfield et al. 2015; Frick et al. 2013). Therefore stress, as a potential stimulus of microglial activity, may contribute to the development of various mental disorders.

A number of studies show an association between greater microglial activity and behavioural outcomes that are proxies for depressive and anxiety-like symptoms in animal models. Studies by Wohleb $(2011,2012)$ using the social defeat model showed anxiety-like behaviour positively associated with microglial activity. Couch et al. (2013), using a model that combined social defeat, restraint and tail suspension, observed a pro-inflammatory profile and heightened microglial activity associated with the development of stress-induced anhedonia in mice susceptible to depression following exposure to stress. These changes in the microglial profile were not present in 'resilient' animals that did not develop depressive symptoms following the stress protocol.

Social defeat has been used as a behavioural correlate for depression, as it provides a comprehensive representation of depressive-like symptoms that can be measured in animals (Hollis and Kabbaj 2014). Similarly, social isolation may be used as a stress paradigm in weaning, adolescent or adult rats, and has been associated with reduced preference for sucrose (Krishnan and Nestler 2011) and reduced swimming during the forced swim test (Djordjevic et al. 2012), both depressivelike symptom paradigms. Though the nature of stress and adversity factors linked to mental illness is complex (Bagot et al. 2014; Howes and Murray 2014), the animal models used in the studies reviewed provide a useful indicator that a range of psychosocial stressors, including both individual (e.g. restraint) and social (e.g. social isolation and defeat), are capable of increasing microglial activity. Moreover, anti-inflammatory medication has been found to reduce depression-like behavioural deficits and reduce microglial activity (Burke et al. 2014; Hinwood et al. 2012; Henry et al. 2008), providing further support for a mechanistic link between microglial activity and psychiatric symptoms.

Three of the studies included in our search specifically examined the effect of prenatal stress on microglial changes and found significant increases in Iba-1 activity (Ślusarczyk et al. 2015; Diz-Chaves et al. 2013, 2012). 
Of these, the two by Diz-Chaves et al. $(2012,2013)$ found potentiated responses in prenatally stressed animals that were subsequently given an immune challenge in adulthood. Similarly, another study found that a prenatal immune challenge left mice more susceptible to markedly potentiated responses to stress during their peripubertal period (Giovanoli et al. 2013). The effects of maternal/ early-life stress on microglial activity closely resembled that caused by pathogenic immune challenge in rodents (Juckel et al. 2011; Bland et al. 2010). Such studies support the idea of stress leading to microglial priming, where an initial stimulation early in life primes microglia, leading to an exaggerated response of the microglia to a second inflammatory stimulus following initial stimulation (Frank et al. 2007). This underlies the 'two-hit' hypothesis (Fig. 3). This hypothesis proposes that early-life stress sensitises microglial cells so that there is an exaggerated elevation of microglial activity to stress in late adolescence or adulthood, leading to brain changes that underlie the development of a mental disorder (Hickie et al. 2009). As demonstrated by the preclinical studies identified here, many forms of psychosocial stress are able to stimulate microglial activity throughout the brain, and in several cases, prenatal stress exposure was sufficient to cause lasting changes in microglial response.

It is beyond the scope of this review to examine the effects of immune stressors such as LPS and cytokine administration on microglial activity, which have been described extensively elsewhere (Harry 2013; Juckel et al. 2011; Dantzer et al. 2008) and clearly show up regulation of microglial markers. A number of the studies included in our search demonstrated that while stress alone is sufficient to increase Iba-1-activity in several areas of the brain, a later immune challenge ('second-hit') potentiated the Iba-1 signal (Ślusarczyk et al. 2015; Diz-Chaves et al. 2012, 2013; Giovanoli et al. 2013; Wohleb et al. 2012; Yoo et al. 2011).

\section{Limitations of current evidence}

There was notable variability in responses seen across the studies. This may simply be the result of methodological differences; each of the stress regimes differs in terms of their severity and duration. There is also some overlap of stress protocols; prior to the chronic restraint protocol used by Tynan et al. (2010), animals were individually housed for a minimum of 1 week to acclimatise. It is difficult then to separate the effects of chronic restraint from the effects of social isolation, which were described by Schiavone et al. (2009). However, it is interesting to note, that within the same lab, undergoing an identical stress regime; we observed that Wohleb et al. $(2011,2012)$ reported variability of approximately 1.5 -fold difference in the magnitude of the control vs. stressed groups (both drug naïve) between the two studies. This variability may result from a number of factors, including the small group sizes of both studies $(n=3-5)$, slight differences in the methodologies; mice were handled and given vehicle administrations either just prior to social defeat or $14 \mathrm{~h}$ after social defeat cycles or possibly as a result of the stressor itself. Here, repeated social defeat introduced an intruder (typically a retired breeder) into an established colony of mice, leading to the establishment of dominance over the original colony (i.e. aggression). The physically damaging nature of this stressor can lead to an injury triggering the immune system, together with the psychosocial stress response, which may account for increased variability across studies.

The study by Kreisel et al. (2014) demonstrates that stress duration is an important consideration. Exposure to variable stressors for an acute period ( 2 days) resulted in upregulated Iba-1 expression via microglial proliferation. In contrast, chronic exposure to this same regime led subsequently to significant decreases within the hippocampus
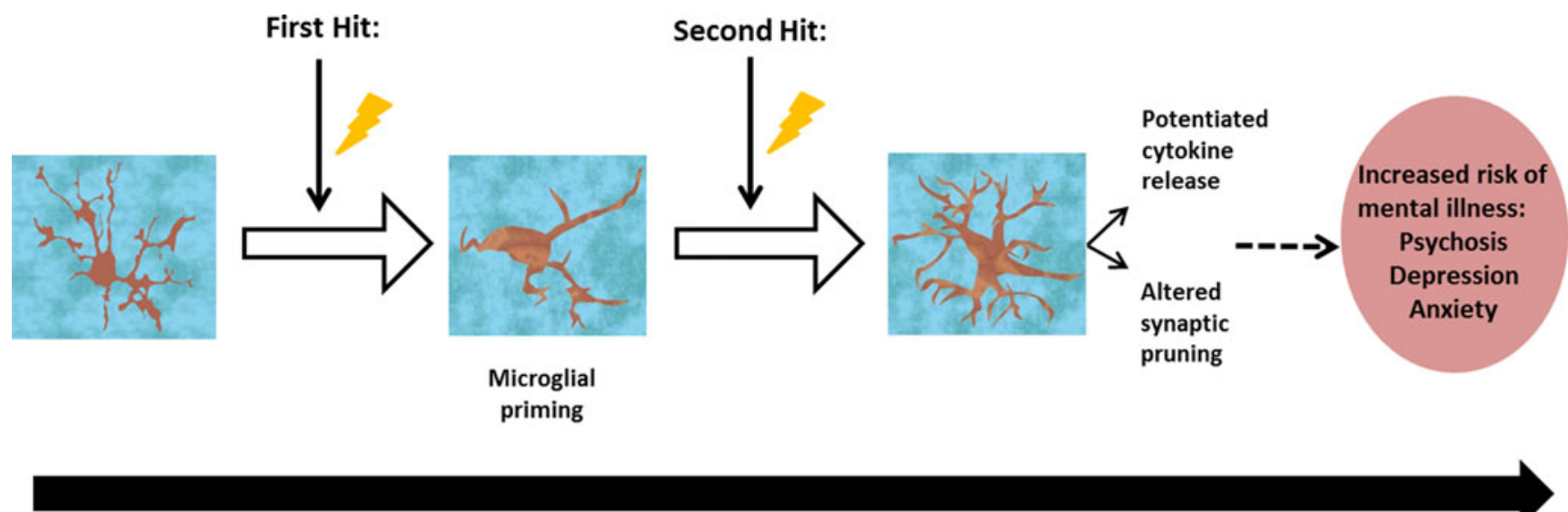

Prenatal / Early life

Adolescence / Early adulthood

\section{Adulthood}

Fig. 3 The 'two-hit' hypothesis: exposure to prenatal/early-life stress (lightning bolt) may act to prime microglia within the CNS so that a subsequent challenge later in life, either in adolescence or adulthood invokes a potentiated microglial response, leading to an increased risk of developing a mental illness 
as a result of increased microglial apoptosis. In addition to this, variations in response and magnitude may be due to species and sex differences, the latter being demonstrated by the two studies by Diz-Chaves et al. (2012, 2013), which showed slight differences in Iba-1 expression within specific areas of the mouse hippocampus. A recent study by Bollinger et al. (2015) also showed sex differences in Iba-1 expression in the rat prefrontal cortex. While there was no difference in the total number of microglia, morphological studies showed unstressed female rats had a greater proportion of primed to ramified microglia than males, suggesting greater basal microglial activity. In response to restraint stress, the proportion of primed microglia decreased in female rats, indicating an inhibitory effect of stress, whereas there was no significant change observed in the males.

Several markers for microglia have been identified (Table 1). Of these, Iba-1 is one of the most commonly used given its CNS selectivity for microglia and infiltrating macrophage (Wohleb et al. 2013). Hence, Iba-1 has been predominantly used to determine information regarding the morphological changes and distribution of microglia in response to pathological and non-pathological challenge. In healthy environments, the majority of microglia have a ramified process morphology with multiple branches that extend as sensors for potential challenges (Nimmerjahn et al. 2005). When a challenge is present, these cells become amoeboid-like, with enlarged soma, fewer branches and processes (Davalos et al. 2005; Stence et al. 2001). However, these stimulated microglia are a heterogeneous mix of cells, which functionally can be divided into pro-inflammatory (M1) and anti-inflammatory (M2) states and, more recently, other phenotypes have been identified (Crain et al. 2013). Of these Mhem, Mox, and M4 show major immunomodulatory and anti-inflammatory properties (Hu et al. 2015; Naito et al. 2014; Moore et al. 2013). In responding to a challenge, M1 microglial cells are the initial source of pro-inflammatory cytokines, such as IL-1 $\beta$ and IL-6, whereas M2 microglia respond secondary, leading to the release of anti-inflammatory signals to restore the system back to normal. Alone therefore, Iba-1 measures provide morphological but limited functional information regarding the CNS response to stress challenges. Alongside Iba-1, several of the studies included additional measures such as cytokine levels to ascertain the inflammatory effects (pro- vs. anti-) of stress. These findings were in line with previous studies of acute stress on pro-inflammatory cytokine induction (Himmerich et al. 2013; O’Connor et al. 2003).

\section{Future directions and implications for new treatments}

Given the growing body of preclinical evidence indicating that stress leads to microglial priming, we suggest that further work in this area focus on two areas. First, preclinical studies are needed to elucidate mechanisms underlying priming and ways to block subsequent effects of stress. Second, clinical studies are needed to determine if priming occurs in humans.

Notwithstanding this, the evidence that stress both increases the risk of a number of mental disorders and leads to elevated microglial activity suggests that targeting this mechanism could treat or even prevent some mental disorders. Some of the studies analysed here have found that treatment with minocycline reversed some stress-induced microglial changes (Hinwood et al. 2012, 2013). Recent clinical studies using minocycline as an adjunctive treatment for patients with schizophrenia have shown promising early results, particularly in the treatment of negative and cognitive symptoms (Chaudhry et al. 2012; Levkovitz et al. 2010). Other promising targets include inhibitors of the enzyme cyclooxygenase-2 (COX-2), which is involved in inflammation signalling (Keller et al. 2013; Müller et al. 2013). Celecoxib, a COX-2 inhibitor given alongside amisulpride improved the therapeutic outcome of early-diagnosed schizophrenic patients when compared with amisulpride alone in a recent 6-week doubleblind study (Müller et al. 2010). The findings we review here suggest that targeting inflammation-pathways of susceptible individuals may help to increase resilience to future stress and attenuate the exaggerated responses of primed microglia.

The effects of psychosocial stress on Iba-1 activity were predominantly examined within the prefrontal cortex and hippocampus. However, Tynan et al. (2010) comprehensively examined multiple brain regions from rats exposed to chronic restraint and found significant changes throughout the CNS. Nevertheless, it remains unclear to what extent the changes in Iba-1 activity occur globally, or are regionally selective following the other forms of psychosocial stress used. Future studies to explore this question and the pathways by which different brain regions receive/respond to stress signals will prove useful.

Another important area of focus for future research is to test the link between microglial priming, two-hit susceptibility and later development of mental health disorders. Microglial priming has been studied in relation to neurodegenerative disorders (Perry and Holmes 2014), and a recent morphometry study has found evidence of increased microglial priming in middleaged patients with depression who died by suicide compared with healthy controls (Torres-Platas et al. 2014). Further developments in the field of microglial activity and priming have the potential for making important changes in our understanding and treatment of mental disorders in the future.

\section{Conclusions}

Our systematic review indicates that stress exposure reliably leads to a microglial response in hippocampus and prefrontal cortical regions, and there is some evidence to suggest similar effects in other regions as well. 


\section{Compliance with ethical standards}

Declaration of interest Dr. Howes has received investigator-initiated research funding from and/or participated in advisory/ speaker meetings organised by Astra-Zeneca, Autifony, BMS, Eli Lilly, Jansenn, Lundbeck, Lyden-Delta, Otsuka, Servier, Sunovion and Roche. This study was funded by a Medical Research Council (UK) grant to Dr. Howes (grant number MC-A656-5QD30) and a Maudsley Charity Grant (number 666) to Dr. Howes and the National Institute for Health Research (NIHR) Biomedical Research Centre at South London and Maudsley NHS Foundation Trust and King's College London. The views expressed are those of the author(s) and not necessarily those of the NHS, the NIHR or the Department of Health.

Open Access This article is distributed under the terms of the Creative Commons Attribution 4.0 International License (http:// creativecommons.org/licenses/by/4.0/), which permits unrestricted use, distribution, and reproduction in any medium, provided you give appropriate credit to the original author(s) and the source, provide a link to the Creative Commons license, and indicate if changes were made.

\section{References}

Adzic M, Djordjevic J, Djordjevic A, Niciforovic A, Demonacos C, Radojcic M, Krstic-Demonacos M (2009) Acute or chronic stress induce cell compartment-specific phosphorylation of glucocorticoid receptor and alter its transcriptional activity in Wistar rat brain. J Endocrinol 202:87-97

Aloisi F (2001) Immune function of microglia. Glia 36:165-179

Arnaout MA (1990) Structure and function of the leukocyte adhesion molecules CD11/CD18. Blood 75:1037-1050

Aronsson M, Fuxe K, Dong Y, Agnati LF, Okret S, Gustafsson JA (1988) Localization of glucocorticoid receptor mRNA in the male rat brain by in situ hybridization. Proc Natl Acad Sci U S A 85:9331-9335

Bagot RC, Labonté B, Peña CJ, Nestler EJ (2014) Epigenetic signaling in psychiatric disorders: stress and depression. Dialogues Clin Neurosci 16:281-295

Baquedano E, García-Cáceres C, Diz-Chaves Y, Lagunas N, Calmarza-Font I, Azcoitia I, Garcia-Segura LM, Argente J, Chowen JA, Frago LM (2011) Prenatal stress induces longterm effects in cell turnover in the hippocampushypothalamus-pituitary axis in adult male rats. PLoS One 6: e27549

Benjet C, Borges G, Medina-Mora ME (2010) Chronic childhood adversity and onset of psychopathology during three life stages: childhood, adolescence and adulthood. J Psychiatr Res 44:732-740

Bian Y, Pan Z, Hou Z, Huang C, Li W, Zhao B (2012) Learning, memory, and glial cell changes following recovery from chronic unpredictable stress. Brain Res Bull 88:471-476

Blanchard RJ, McKittrick CR, Blanchard DC (2001) Animal models of social stress: effects on behavior and brain neurochemical systems. Physiol Behav 73:261-271

Bland ST, Beckley JT, Young S, Tsang V, Watkins LR, Maier SF, Bilbo SD (2010) Enduring consequences of early-life infection on glial and neural cell genesis within cognitive regions of the brain. Brain Behav Immun 24:329-338

Bloomfield PS, Selvaraj S, Veronese M, Rizzo G, Bertoldo A, Owen DR, Bloomfield MAP, Bonoldi I, Kalk N, Turkheimer F, et al. (2015) Microglial activity in people at ultra high risk of psychosis and in schizophrenia: an [(11)C]PBR28 PET brain imaging study. Am J Psychiatry. appiajp201514101358.
Bollinger JL, Bergeon Burns CM, Wellman CL (2015) Differential effects of stress on microglial cell activation in male and female medial prefrontal cortex. Brain Behav Immun.

Brevet M, Kojima H, Asakawa A, Atsuchi K, Ushikai M, Ataka K, Inui A, Kimura H, Sevestre H, Fujimiya M (2010) Chronic foot-shock stress potentiates the influx of bone marrow-derived microglia into hippocampus. J Neurosci Res 88:1890-1897

Brown GC, Neher JJ (2014) Microglial phagocytosis of live neurons. Nat Rev Neurosci 15:209-216

Brunson KL, Avishai-Eliner S, Hatalski CG, Baram TZ (2001a) Neurobiology of the stress response early in life: evolution of a concept and the role of corticotropin releasing hormone. Mol Psychiatry 6:647-656

Brunson KL, Eghbal-Ahmadi M, Bender R, Chen Y, Baram TZ (2001b) Long-term, progressive hippocampal cell loss and dysfunction induced by early-life administration of corticotropin-releasing hormone reproduce the effects of early-life stress. Proc Natl Acad Sci U S A 98:8856-8861

Burke NN, Kerr DM, Moriarty O, Finn DP, Roche M (2014) Minocycline modulates neuropathic pain behaviour and cortical M1-M2 microglial gene expression in a rat model of depression. Brain Behav Immun 42:147-156

Chaudhry IB, Hallak J, Husain N, Minhas F, Stirling J, Richardson P, Dursun S, Dunn G, Deakin B (2012) Minocycline benefits negative symptoms in early schizophrenia: a randomised double-blind placebo-controlled clinical trial in patients on standard treatment. J Psychopharmacol Oxf Engl 26:1185-1193

Cho BP, Song DY, Sugama S, Shin DH, Shimizu Y, Kim SS, Kim YS, Joh TH (2006) Pathological dynamics of activated microglia following medial forebrain bundle transection. Glia 53:92-102

Couch Y, Anthony DC, Dolgov O, Revischin A, Festoff B, Santos AI, Steinbusch HW, Strekalova T (2013) Microglial activation, increased TNF and SERT expression in the prefrontal cortex define stress-altered behaviour in mice susceptible to anhedonia. Brain Behav Immun 29:136-146

Crain JM, Nikodemova M, Watters JJ (2013) Microglia express distinct M1 and M2 phenotypic markers in the postnatal and adult central nervous system in male and female mice. J Neurosci Res 91:1143-1151

Danese A, Moffitt TE, Pariante CM, Ambler A, Poulton R, Caspi A (2008) Elevated inflammation levels in depressed adults with a history of childhood maltreatment. Arch Gen Psychiatry 65:409-415

Dantzer R, O'Connor JC, Freund GG, Johnson RW, Kelley KW (2008) From inflammation to sickness and depression: when the immune system subjugates the brain. Nat Rev Neurosci 9:46-56

Davalos D, Grutzendler J, Yang G, Kim JV, Zuo Y, Jung S, Littman DR, Dustin ML, Gan W-B (2005) ATP mediates rapid microglial response to local brain injury in vivo. Nat Neurosci 8:752-758

Denker SP, Ji S, Dingman A, Lee SY, Derugin N, Wendland MF, Vexler ZS (2007) Macrophages are comprised of resident brain microglia not infiltrating peripheral monocytes acutely after neonatal stroke. J Neurochem 100:893-904

Diorio D, Viau V, Meaney MJ (1993) The role of the medial prefrontal cortex (cingulate gyrus) in the regulation of hypothalamicpituitary-adrenal responses to stress. J Neurosci Off J Soc Neurosci 13:3839-3847

Diz-Chaves Y, Pernía O, Carrero P, Garcia-Segura LM (2012) Prenatal stress causes alterations in the morphology of microglia and the inflammatory response of the hippocampus of adult female mice. J Neuroinflammation 9:71

Diz-Chaves Y, Astiz M, Bellini MJ, Garcia-Segura LM (2013) Prenatal stress increases the expression of proinflammatory cytokines and exacerbates the inflammatory response to LPS in the hippocampal formation of adult male mice. Brain Behav Immun 28:196-206

Djordjevic A, Djordjevic J, Elaković I, Adzic M, Matić G, Radojcic MB (2012) Fluoxetine affects hippocampal plasticity, apoptosis and 
depressive-like behavior of chronically isolated rats. Prog Neuropsychopharmacol Biol Psychiatry 36:92-100

Frank MG, Baratta MV, Sprunger DB, Watkins LR, Maier SF (2007) Microglia serve as a neuroimmune substrate for stress-induced potentiation of CNS pro-inflammatory cytokine responses. Brain Behav Immun 21:47-59

Frank MG, Hershman SA, Weber MD, Watkins LR, Maier SF (2014) Chronic exposure to exogenous glucocorticoids primes microglia to pro-inflammatory stimuli and induces NLRP 3 mRNA in the hippocampus. Psychoneuroendocrinology 40:191-200

Frick LR, Williams K, Pittenger C (2013) Microglial dysregulation in psychiatric disease. Clin Dev Immunol 2013:608654

Giovanoli S, Engler H, Engler A, Richetto J, Voget M, Willi R, Winter C, Riva MA, Mortensen PB, Feldon J et al (2013) Stress in puberty unmasks latent neuropathological consequences of prenatal immune activation in mice. Science 339:1095-1099

Gold PW (2015) The organization of the stress system and its dysregulation in depressive illness. Mol Psychiatry 20:32-47

Hains BC, Waxman SG (2006) Activated microglia contribute to the maintenance of chronic pain after spinal cord injury. J Neurosci Off J Soc Neurosci 26:4308-4317

Harry GJ (2013) Microglia during development and aging. Pharmacol Ther 139:313-326

Henry CJ, Huang Y, Wynne A, Hanke M, Himler J, Bailey MT, Sheridan JF, Godbout JP (2008) Minocycline attenuates lipopolysaccharide (LPS)-induced neuroinflammation, sickness behavior, and anhedonia. J Neuroinflammation 5:15

Hickie IB, Banati R, Stewart CH, Stewart CH, Lloyd AR (2009) Are common childhood or adolescent infections risk factors for schizophrenia and other psychotic disorders? Med J Aust 190:S17-S21

Himmerich H, Fischer J, Bauer K, Kirkby KC, Sack U, Krügel U (2013) Stress-induced cytokine changes in rats. Eur Cytokine Netw 24:97-103

Hinojosa AE, Garcia-Bueno B, Leza JC, Madrigal JLM (2011) CCL2/ MCP-1 modulation of microglial activation and proliferation. J Neuroinflammation 8:77

Hinwood M, Morandini J, Day TA, Walker FR (2012) Evidence that microglia mediate the neurobiological effects of chronic psychological stress on the medial prefrontal cortex. Cereb Cortex N Y N 1991(22):1442-1454

Hinwood M, Tynan RJ, Charnley JL, Beynon SB, Day TA, Walker FR (2013) Chronic stress induced remodeling of the prefrontal cortex: structural re-organization of microglia and the inhibitory effect of minocycline. Cereb Cortex N Y N 1991(23):1784-1797

Hollis F, Kabbaj M (2014) Social defeat as an animal model for depression. ILAR J Natl Res Counc Inst Lab Anim Resour 55:221-232

Howes OD, Murray RM (2014) Schizophrenia: an integrated sociodevelopmental-cognitive model. Lancet Lond Engl 383: $1677-1687$

Hu X, Leak RK, Shi Y, Suenaga J, Gao Y, Zheng P, Chen J (2015) Microglial and macrophage polarization - new prospects for brain repair. Nat Rev Neurol 11:56-64

Huntington ND, Tarlinton DM (2004) CD45: direct and indirect government of immune regulation. Immunol Lett 94:167-174

Imai T, Hieshima K, Haskell C, Baba M, Nagira M, Nishimura M, Kakizaki M, Takagi S, Nomiyama H, Schall TJ et al (1997) Identification and molecular characterization of fractalkine receptor CX3CR1, which mediates both leukocyte migration and adhesion. Cell 91:521-530

Ito D, Imai Y, Ohsawa K, Nakajima K, Fukuuchi Y, Kohsaka S (1998) Microglia-specific localisation of a novel calcium binding protein, Iba1. Brain Res Mol Brain Res 57:1-9

Johnson JD, Campisi J, Sharkey CM, Kennedy SL, Nickerson M, Greenwood BN, Fleshner M (2005) Catecholamines mediate stress-induced increases in peripheral and central inflammatory cytokines. Neuroscience 135:1295-1307
Johnson JD, Cortez V, Kennedy SL, Foley TE, Hanson H, Fleshner M (2008) Role of central beta-adrenergic receptors in regulating proinflammatory cytokine responses to a peripheral bacterial challenge. Brain Behav Immun 22:1078-1086

Johnson JD, Zimomra ZR, Stewart LT (2013) Beta-adrenergic receptor activation primes microglia cytokine production. J Neuroimmunol 254:161-164

Juckel G, Manitz MP, Brüne M, Friebe A, Heneka MT, Wolf RJ (2011) Microglial activation in a neuroinflammational animal model of schizophrenia - a pilot study. Schizophr Res 131:96-100

Keller WR, Kum LM, Wehring HJ, Koola MM, Buchanan RW, Kelly DL (2013) A review of anti-inflammatory agents for symptoms of schizophrenia. J Psychopharmacol Oxf Engl 27:337-342

Kessler RC, McLaughlin KA, Green JG, Gruber MJ, Sampson NA, Zaslavsky AM, Aguilar-Gaxiola S, Alhamzawi AO, Alonso J, Angermeyer $\mathrm{M}$ et al (2010) Childhood adversities and adult psychopathology in the WHO World Mental Health Surveys. Br J Psychiatry J Ment Sci 197:378-385

Kettenmann H, Hanisch U-K, Noda M, Verkhratsky A (2011) Physiology of microglia. Physiol Rev 91:461-553

Kettenmann H, Kirchhoff F, Verkhratsky A (2013) Microglia: new roles for the synaptic stripper. Neuron 77:10-18

Khandaker GM, Pearson RM, Zammit S, Lewis G, Jones PB (2014) Association of serum interleukin 6 and $\mathrm{C}$-reactive protein in childhood with depression and psychosis in young adult life: a population-based longitudinal study. JAMA Psychiatry 71 : $1121-1128$

Kojo A, Yamada K, Kubo K, Yamashita A, Yamamoto T (2010) Occlusal disharmony in mice transiently activates microglia in hippocampal CA1 region but not in dentate gyrus. Tohoku J Exp Med 221:237-243

Konsman JP, Parnet P, Dantzer R (2002) Cytokine-induced sickness behaviour: mechanisms and implications. Trends Neurosci 25: 154-159

Kopp BL, Wick D, Herman JP (2013) Differential effects of homotypic vs. heterotypic chronic stress regimens on microglial activation in the prefrontal cortex. Physiol Behav 122:246-252

Kreisel T, Frank MG, Licht T, Reshef R, Ben-Menachem-Zidon O, Baratta MV, Maier SF, Yirmiya R (2014) Dynamic microglial alterations underlie stress-induced depressive-like behavior and suppressed neurogenesis. Mol Psychiatry 19:699-709

Krishnan V, Nestler EJ (2011) Animal models of depression: molecular perspectives. Curr Top Behav Neurosci 7:121-147

Lawson LJ, Perry VH, Dri P, Gordon S (1990) Heterogeneity in the distribution and morphology of microglia in the normal adult mouse brain. Neuroscience 39:151-170

Lemaire V, Koehl M, Le Moal M, Abrous DN (2000) Prenatal stress produces learning deficits associated with an inhibition of neurogenesis in the hippocampus. Proc Natl Acad Sci U S A 97: 11032-11037

Levkovitz Y, Mendlovich S, Riwkes S, Braw Y, Levkovitch-Verbin H, Gal G, Fennig S, Treves I, Kron S (2010) A double-blind, randomized study of minocycline for the treatment of negative and cognitive symptoms in early-phase schizophrenia. J Clin Psychiatry 71:138-149

Loane DJ, Kumar A, Stoica BA, Cabatbat R, Faden AI (2014) Progressive neurodegeneration after experimental brain trauma: association with chronic microglial activation. J Neuropathol Exp Neurol 73:14-29

Lordi B, Protais P, Mellier D, Caston J (1997) Acute stress in pregnant rats: effects on growth rate, learning, and memory capabilities of the offspring. Physiol Behav 62:1087-1092

Louveau A, Smirnov I, Keyes TJ, Eccles JD, Rouhani SJ, Peske JD, Derecki NC, Castle D, Mandell JW, Lee KS, et al. (2015) 
Structural and functional features of central nervous system lymphatic vessels. Nature.

Martinon F, Burns K, Tschopp J (2002) The inflammasome: a molecular platform triggering activation of inflammatory caspases and processing of proIL-beta. Mol Cell 10:417-426

McEwen BS (2000) The neurobiology of stress: from serendipity to clinical relevance. Brain Res 886:172-189

McEwen BS, Gould EA, Sakai RRs (1992) The vulnerability of the hippocampus to protective and destructive effects of glucocorticoids in relation to stress. Br J Psychiatry. Suppl. 18-23.

McNamee EN, Griffin EW, Ryan KM, Ryan KJ, Heffernan S, Harkin A, Connor TJ (2010) Noradrenaline acting at beta-adrenoceptors induces expression of IL-1 beta and its negative regulators IL-1 ra and IL-1RII, and drives an overall anti-inflammatory phenotype in rat cortex. Neuropharmacology 59:37-48

Meaney MJ, Tannenbaum B, Francis D, Bhatnagar S, Shanks N, Viau V, O'Donnell D, Plotsky PM (1994) Early environmental programming hypothalamic-pituitary-adrenal responses to stress. Semin Neurosci 6:247-259

Meerschaert J, Furie MB (1995) The adhesion molecules used by monocytes for migration across endothelium include CD11a/CD18, CD11b/ CD18, and VLA-4 on monocytes and ICAM-1, VCAM-1, and other ligands on endothelium. J Immunol Baltim Md 1950(154):4099-4112

Mizutani M, Pino PA, Saederup N, Charo IF, Ransohoff RM, Cardona AE (2012) The fractalkine receptor but not CCR2 is present on microglia from embryonic development throughout adulthood. J Immunol 188(1):29-36

Moore KJ, Sheedy FJ, Fisher EA (2013) Macrophages in atherosclerosis: a dynamic balance. Nat Rev Immunol 13:709-721

Morgan JT, Chana G, Abramson I, Semendeferi K, Courchesne E, Everall IP (2012) Abnormal microglial-neuronal spatial organization in the dorsolateral prefrontal cortex in autism. Brain Res 1456:72-81

Müller N, Krause D, Dehning S, Musil R, Schennach-Wolff R, Obermeier M, Möller H-J, Klauss V, Schwarz MJ, Riedel M (2010) Celecoxib treatment in an early stage of schizophrenia: results of a randomized, doubleblind, placebo-controlled trial of celecoxib augmentation of amisulpride treatment. Schizophr Res 121:118-124

Müller N, Myint A-M, Krause D, Weidinger E, Schwarz MJ (2013) Antiinflammatory treatment in schizophrenia. Prog Neuropsychopharmacol Biol Psychiatry 42:146-153

Nair A, Bonneau RH (2006) Stress-induced elevation of glucocorticoids increases microglia proliferation through NMDA receptor activation. J Neuroimmunol 171:72-85

Naito Y, Takagi T, Higashimura Y (2014) Heme oxygenase-1 and antiinflammatory M2 macrophages. Arch Biochem Biophys 564:83-88

Nimmerjahn A, Kirchhoff F, Helmchen F (2005) Resting microglial cells Are highly dynamic surveillants of brain parenchyma in vivo. Science 308:1314-1318

O'Connor KA, Johnson JD, Hansen MK, Wieseler Frank JL, Maksimova E, Watkins LR, Maier SF (2003) Peripheral and central proinflammatory cytokine response to a severe acute stressor. Brain Res 991:123-132

Ohsawa K, Imai Y, Kanazawa H, Sasaki Y, Kohsaka S (2000) Involvement of Ibal in membrane ruffling and phagocytosis of macrophages/microglia. J Cell Sci 113(Pt 17):3073-3084

Paolicelli RC, Bolasco G, Pagani F, Maggi L, Scianni M, Panzanelli P, Giustetto M, Ferreira TA, Guiducci E, Dumas L et al (2011) Synaptic pruning by microglia is necessary for normal brain development. Science 333:1456-1458

Park JH, Yoo K-Y, Lee CH, Kim IH, Shin BN, Choi JH, Park JH, Hwang IK, Won M-H (2011) Comparison of glucocorticoid receptor and ionized calcium-binding adapter molecule 1 immunoreactivity in the adult and aged gerbil hippocampus following repeated restraint stress. Neurochem Res 36:1037-1045

Parkhurst CN, Yang G, Ninan I, Savas JN, Yates JR, Lafaille JJ, Hempstead BL, Littman DR, Gan W-B (2013) Microglia promote learning-dependent synapse formation through BDNF. Cell 155: 1596-1609

Perry VH, Holmes C (2014) Microglial priming in neurodegenerative disease. Nat Rev Neurol 10(4):217-24

Räikkönen K, Pesonen A-K, O’Reilly JR, Tuovinen S, Lahti M, Kajantie E, Villa P, Laivuori H, Hämäläinen E, Seckl JR, et al. (2015) Maternal depressive symptoms during pregnancy, placental expression of genes regulating glucocorticoid and serotonin function and infant regulatory behaviors. Psychol Med; 1-10.

Ramprasad MP, Terpstra V, Kondratenko N, Quehenberger O, Steinberg D (1996) Cell surface expression of mouse macrosialin and human CD68 and their role as macrophage receptors for oxidized low density lipoprotein. Proc Natl Acad Sci U S A 93:14833-14838

Réus GZ, Fries GR, Stertz L, Badawy M, Passos IC, Barichello T, Kapczinski F, Quevedo J (2015) The role of inflammation and microglial activation in the pathophysiology of psychiatric disorders. Neuroscience 300:141-154

Saito N, Pulford KA, Breton-Gorius J, Massé JM, Mason DY, Cramer EM (1991) Ultrastructural localization of the CD68 macrophageassociated antigen in human blood neutrophils and monocytes. Am J Pathol 139:1053-1059

Sánchez MM, Aguado F, Sánchez-Toscano F, Saphier D (1998) Neuroendocrine and immunocytochemical demonstrations of decreased hypothalamo-pituitary-adrenal axis responsiveness to restraint stress after long-term social isolation. Endocrinology 139:579-587

Schafer DP, Stevens B (2010) Synapse elimination during development and disease: immune molecules take centre stage. Biochem Soc Trans 38:476-481

Schiavone S, Sorce S, Dubois-Dauphin M, Jaquet V, Colaianna M, Zotti M, Cuomo V, Trabace L, Krause K-H (2009) Involvement of NOX2 in the development of behavioral and pathologic alterations in isolated rats. Biol Psychiatry 66:384-392

Scott KM, McLaughlin KA, Smith DAR, Ellis PM (2012) Childhood maltreatment and DSM-IV adult mental disorders: comparison of prospective and retrospective findings. Br J Psychiatry J Ment Sci 200:469-475

Selenica M-LB, Alvarez JA, Nash KR, Lee DC, Cao C, Lin X, Reid P, Mouton PR, Morgan D, Gordon MN (2013) Diverse activation of microglia by chemokine (C-C motif) ligand 2 overexpression in brain. J Neuroinflammation 10:86

Sierra A, Gottfried-Blackmore A, Milner TA, McEwen BS, Bulloch K (2008) Steroid hormone receptor expression and function in microglia. Glia 56:659-674

Ślusarczyk J, Trojan E, Głombik K, Budziszewska B, Kubera M, Lasoń W, Popiołek-Barczyk K, Mika J, Wędzony K, Basta-Kaim A (2015) Prenatal stress is a vulnerability factor for altered morphology and biological activity of microglia cells. Front Cell Neurosci 9:82

St Pierre Y, Watts TH (1991) Characterization of the signaling function of MHC class II molecules during antigen presentation by B cells. J Immunol Baltim Md 1950(147):2875-2882

Stalder M, Phinney A, Probst A, Sommer B, Staufenbiel M, Jucker M (1999) Association of microglia with amyloid plaques in brains of APP23 transgenic mice. Am J Pathol 154:1673-1684

Stence N, Waite M, Dailey ME (2001) Dynamics of microglial activation: a confocal time-lapse analysis in hippocampal slices. Glia 33:256-266

Stroup DF, Berlin JA, Morton SC, Olkin I, Williamson GD, Rennie D, Moher D, Becker BJ, Sipe TA, Thacker SB (2000) Meta-analysis of observational studies in epidemiology: a proposal for reporting. Metaanalysis Of Observational Studies in Epidemiology (MOOSE) group. JAMA 283(15):2008-12

Sugama S, Fujita M, Hashimoto M, Conti B (2007) Stress induced morphological microglial activation in the rodent brain: involvement of interleukin-18. Neuroscience 146:1388-1399

Torres-Platas SG, Cruceanu C, Chen GG, Turecki G, Mechawar N (2014) Evidence for increased microglial priming and macrophage 
recruitment in the dorsal anterior cingulate white matter of depressed suicides. Brain Behav Immun 42:50-59

Tremblay M-È, Lowery RL, Majewska AK (2010) Microglial interactions with synapses are modulated by visual experience. PLoS Biol 8:e1000527

Tynan RJ, Naicker S, Hinwood M, Nalivaiko E, Buller KM, Pow DV, Day TA, Walker FR (2010) Chronic stress alters the density and morphology of microglia in a subset of stress-responsive brain regions. Brain Behav Immun 24:1058-1068

van Berckel BN, Bossong MG, Boellaard R, Kloet R, Schuitemaker A, Caspers E, Luurtsema G, Windhorst AD, Cahn W, Lammertsma AA et al (2008) Microglia activation in recent-onset schizophrenia: a quantitative (R)-[11C]PK11195 positron emission tomography study. Biol Psychiatry 64:820-822

Varese F, Smeets F, Drukker M, Lieverse R, Lataster T, Viechtbauer W, Read J, van Os J, Bentall RP (2012) Childhood adversities increase the risk of psychosis: a meta-analysis of patient-control, prospectiveand cross-sectional cohort studies. Schizophr Bull 38:661-671

Walker FR, Nilsson M, Jones K (2013) Acute and chronic stress-induced disturbances of microglial plasticity, phenotype and function. Curr Drug Targets 14:1262-1276

Walker FR, Beynon SB, Jones KA, Zhao Z, Kongsui R, Cairns M, Nilsson M (2014) Dynamic structural remodelling of microglia in health and disease: a review of the models, the signals and the mechanisms. Brain Behav Immun 37:1-14
Wan W, Wetmore L, Sorensen CM, Greenberg AH, Nance DM (1994) Neural and biochemical mediators of endotoxin and stress-induced c-fos expression in the rat brain. Brain Res Bull 34:7-14

Wohleb ES, Hanke ML, Corona AW, Powell ND, Stiner LM, Bailey MT, Nelson RJ, Godbout JP, Sheridan JF (2011) $\beta$-Adrenergic receptor antagonism prevents anxiety-like behavior and microglial reactivity induced by repeated social defeat. J Neurosci Off J Soc Neurosci 31: 6277-6288

Wohleb ES, Fenn AM, Pacenta AM, Powell ND, Sheridan JF, Godbout JP (2012) Peripheral innate immune challenge exaggerated microglia activation, increased the number of inflammatory CNS macrophages, and prolonged social withdrawal in socially defeated mice. Psychoneuroendocrinology 37:1491-1505

Wohleb ES, Powell ND, Godbout JP, Sheridan JF (2013) Stress-induced recruitment of bone marrow-derived monocytes to the brain promotes anxiety-like behavior. J Neurosci Off J Soc Neurosci 33: $13820-13833$

Xu J, Ling EA (1994) Upregulation and induction of surface antigens with special reference to MHC class II expression in microglia in postnatal rat brain following intravenous or intraperitoneal injections of lipopolysaccharide. J Anat 184(Pt 2):285-296

Yoo K-Y, Lee CH, Park JH, Hwang IK, Park OK, Kwon S-H, Choi JH, Kim D, Kwon Y-G, Kim Y-M et al (2011) Antioxidant enzymes are differently changed in experimental ischemic hippocampal CA1 region following repeated restraint stress. J Neurol Sci 302:33-42 